The foxes were calling at the waning moon. Slowly, the constellations were revolving over the dial of his iris, about the black vortex of his pupil. He blinked.

She was lying near him, covered by the sari against the faint bloodless chill which came in the dead time somewhere between moon and sunrise, a dead time in the night or body when the chill came no matter.

For an instant when she took his hand, he felt a sudden warmth, a warmth of flesh and blood dark beneath. And then his fingers chilled. He took back his hand and stood up on the mat. He knew she was watching him as he walked away beneath the waning moon.

The palms were starred, the stars brightening as the dust settled. The air smelled faintly of cow dung and ashes. David went to the unfinished well, deeply shadowed. He kicked a little dirt into the empty pit. It clopped softly as it hit the bottom. He held his cold hand and looked out across the empty land at the dark horizon. His hand had been warm for a moment. He shivered by the empty, unfinished well.

Tomorrow, he would leave.

\title{
America the Beautiful
}

Charles Aukema

When the primary clear light seen at the moment of death implodes beyond the inner eye, you must begin meditation in this fashion: DEAR HELOISE. . . . Think about the free human body you were given, and then think about the many ways you have wasted this difficult-to-obtain, free, and endowed body. When the thumb starts to squeeze the trigger, do you know what happens? Forget Princess Anne. You must think about this human body, and you must meditate upon this irreligious and worldly death.

Say a few words about Nick Piantanida.

Take a look at Lake Erie.

And Heloise?

Observe the masses of pubic hair growing over her whole body. Such a lovely body. Can you see Miss America down there? Notice all the MIGS and Phantoms. Can you see the shadows on the corn fields? Dear Heloise, it looks 
like the Earth caught smallpox and died. If you point the barrel at your left eye and look inside . . . that's the next to the last step, of course . . . and if you turn the gun around, Heloise . . . that's the third to the last step . . . and since human life in the age of darkness is so brief and uncertain, you must meditate upon the folly of worldly aims and the stupidity of these pursuits.

And Heloise?

These are the causes of regret.

If you take a Ruger Single-Six revolver out of your right coat pocket, turn to the wall so that the other customers cannot see what you're holding . . . and Heloise? You must think about how you allowed your mind to be swallowed up in the morass of the world's illusions.

Let us pray for Howard Johnson's coffee.

Forgive me, Father ... the crocodile.

You will end the way your Father ended.

You must think about the gulf that exists between you and the power that posited you in the first place. You have always lived for this day. At least you tried to think of something new.

So it's finished.

Looking for a better future ... through a better job?

Scrap Yard man. Plumber. Opportunity for advancement. Excellent working conditions. JOURNEYMAN MEAT CUTTERS, but if you kill her, you'll give her what she wants . . . ideal for newlyweds or retired couple-"Built to Endure" -HOMES FOR SALE. There is no other alternative. You must meditate upon the chaos that uncontrolled passion has created in your life. So if you want to retain your own self-respect, you must do away with her.

A UNITED JET DID IT LAST TUESDAY.

It took Mrs. Sullivan 28 years to get Mr. Sullivan to Hawaii.

You promised her.

When the perfect wisdom is found inside yourself, you must meditate upon your dissipation of this wisdom in the jungle of the world. She demands that righteousness fulfill its promise and condemn her. You were the man she worshipped and feared. The one righteous man. You were the stern moralist.

The lover is death.

Think about how cheaply you sold yourself to the world.

You just happen to be the instrument.

The punishment will release her. You've always known that ... VISIT THE BEAUTIFUL CAVE OF THE MOUNDS, WISCONSIN'S UNDERGROUND WONDER! And you were supposed to punish her. You were the Father, not the lover. That's all she's ever wanted. SUN TRAILS LEAD YOU TO ENDLESS FUN IN ALBUQUERQUE. And that's why she married you.

Isn't that somewhere in New Mexico?

DISCOVER AMERICA NOW ON A GREYHOUND BUS.

Would that punish her enough? Since all beings happen to be our parents, you must carefully think about your aversion and abandonment of them. Kill her or kill yourself, anything to get rid of this very quiet kind of horror. DISCOVER UTAH IN JULY. Punish her or else give her freedom. You must think about the 
wasteful and vulgar indifference of your young life. Only the two alternatives are left. GREATER MIAMI MEANS MORE. There are no other escapes.

COLORFUL COLORADO INVITES YOU.

COULD YOU ASK FOR MORE?

Once you have exhausted the regrets of your life, you may then begin to meditate on the requirements of death. OUTSIDE OF THAT, YOU RECEIVE A BIG, BRIGHT, PSYCHEDELIC PACKET OF HIGH-COUNTRY VACATION INFORMATION. After you have estimated your own capabilities, you must meditate on one sure line of action. Divorce her and you divorce yourself. INSIDE THIS FASCINATING NEW BOOK ARE 52 EXCITING PAGES, 143 COLOR PICTURES, 14,341 WORDS.

FREE.

She's a part of your guts.

SALE PRICE \$10.97.

But without her life is meaningless.

Cuts a 2" x 4". Cuts on 45-degree bevel. Saws everything from metal to leather. PORTABLE JIG SAW . . . move out of the house . . . get a lawyer. To carry out the commands of this sure line of action, you must meditate on confidence and diligence. Then catch them in the act . . . buy a camera . . . find out where she meets him . . . \$\$DOLLAR \$\$DAYS\$\$ . . DON'T MISS BUDGET BASEMENT DOLLAR DAYS. Save the memory of her talents in the minds of a thousand sailors, cripples, hunchbacks . . . sell the pictures to a French pornographer after the trial is over ... ${ }^{*} \mathrm{SAVE}^{*}{ }^{*} \mathrm{SAVE}$ "** SAVE $20 \%$ to $50 \%$ TOMORROW LAST DAY!

SAVE $\$ \$ \$ \$ \$$ ANNIVERSARY SALE!!!!!

Collect evidence, bedsheets, photographs.

SINGER “ZIG-ZAG” SEWING MACHINE \$88.

Or else do it yourself.

To avoid error in the choice of the path you must take, you must meditate on the knowledge of your own faults and virtues. A private detective. Bulldozers are uncovering curbs and gutters laid out forty years ago, Dear God, many of these properties are jungles today, but to tune in with the mindlessness of the action, you must meditate on concepts of intellect and unwavering faith. Apparently, the enzyme deficiency does no harm so far as general health is concerned, although a certain social stigmata has been burned into their hands, their eyes, and their foreheads. In order to keep the mind unsullied by evil, you must meditate upon the qualities of unceasing watchfulness and mental alertness, both of which should be graced with humility. He is reported to have had a faintly blue skin which was passed on to his many progeny and has passed on down the generations since. You must think about spiritual armour and strength of intellect.

Tear out the veins.

Squeeze the heart dry.

Rip it out by the roots.

Or else get a divorce.

Blood.

The machine generates radiation or electron beams of up to 18 million 
volts for treatment of deep-seated cancers, and if she likes that kind of life, tell her to stay there. Drain out all the blood. Sample the French, the Russian, the Chinese, the Korean, the Vietnamese, and live like you have been living for the past three years, but cut off the heart. And tell her not to come back. To acquire the peace of mind born of right motives, right actions, and the altruistic dedication of their results, you must meditate upon them unceasingly. Heloise says: Pressing corduroy (on the wrong side, of course) on a heavy terry cloth towel prevents mashing down the nap or having shiny seams, and the corduroy looks velvety and pretty as new, so let her go off to Asia and find someone else to suck dry. Give Miss America a new wardrobe, a new face-lift, and a new vacation.

Ignore her completely.

Let her do anything she wants to do.

Change your name, your language, and your life.

Just take off and never come back. Take all of your money out of the bank and take off to South America ... take a vacation. He was shot through the left eye by a sniper, his parents were told. How? "I carry 300 rounds of machine gun ammunition and about 200 rounds for my rifle," he wrote home to his parents. He was an ammunition bearer for a machine gun.

How will you punish the bitch?

ERROR BY MATHEWS IN 9TH GIVES HOUSTON 2-1 VICTORY.

All four of you in bed together at the same time.

Dinner by candle light. A few drinks. Invite a different man and woman over to the house every night. The mind, imbued with love and compassion in thought and deed, ought ever to be directed to the service of all sentient beings. You could convert the house into a factory and work it like a production line.

Fill the whole world with love.

Give pleasure to everyone.

And if both of you last long enough, you might be able to corrupt everyone without prejudice. Her speciality would be priests, and your speciality would be nuns. Think of black skirts and tight collars. TWO REICHARDT HOMERS IN INNING TIE RECORD. That might be fun. You and Miss America could sit up in bed every night and tell stories about each body. Through hearing, understanding, and wisdom, you should so comprehend the nature of all things as not to fall into the error of regarding matter and phenomena as real.

This waitress, for instance.

That would be fun.

Remember Eddie Mathews.

Become a machine of pleasure. The American Dream. Plunder for the sake of Old Glory. Cover her face with the flag . . . compact and tight . . . go out and screw them all. Attach yourself to a dream of death endowed with spiritual power and complete knowledge. The horny, hungry, middle-aged hag who keeps searching for a young Ponce de Leon. The precocious teen-ager. The experimental college girl. The bored housewife. The sophisticated piece of plastic statuary. The easy lay. Go out and find the sluts. Seek a delightful solitude endowed with psychic influences as a hermitage.

"Here's you cream, Sir." 
Most of the victims lived in villages on the slope of the volcano several miles from its peak. Creatures tied to trees, towers, buzzsaws, railroad tracks, to almost anything ... look for friends who have beliefs and habits like your own and in whom you can place your trust. And if you think about it, the tied-up heroine is practically the most popular image the theatre has ever devised. Do something. You've got to do something. "The staircase was as hot as a furnace, the kitchen was blazing, and the other downstairs rooms were filled with smoke," Cohen said. Once you have someone waiting up there, you've got to use him at least once an act, whether the play needs him or not. However, split-level plays tend to produce split-level plots. He said his family had been watching television until about 10:45.

I'm sorry.

Bridges spanning the river were destroyed.

Temperature of the Kepung rose to 200 degrees centigrade.

Molten rock poured into Lahar River west of Blitar and into Kepung River near Kediri. "Oh, I'm sorry . . . here, I'll get you some more." Bearing in mind the evils of gluttony, use just enough food to keep the sense of death alive. "The pitcher's empty. Would you bring me some more cream? . . . that's nice, though ... I'm sorry."

"In the newspaper. I've got a brother in Viet Nam."

"Pardon?"

"How's the war going?"

"Yes ... yes, please."

"Care for some more coffee?"

Study the teachings of the Great Sages of all faiths impartially. Give her the freedom to create the Golden Age. Encourage her adultery. If everybody belongs to everybody else, there will be no more wars.

CHICAGO PIGS UP, CATTLE OFF.

Join all men together inside Miss America.

Tenders on May soybeans amounted to 3.5 million bushels.

Some was retendered, but demand was steady.

Think of the possibilities.

Study the beneficent sciences of medicine and astrology, and the profound art of omens. Don't make her a triangle or a pentagon, but an ever growing circle that swallows up all men in the sexual embrace. Then write up the experiment in a sociological journal; or else write up a Horatio Alger story for Fortune. Then adopt the regimen and manner of living that will keep you in good health.

Spread the good news.

Preach the communion of brotherly love.

Adopt devotional practices that will be conducive to your own spiritual development. Bids shall be made in quadruplicate on forms furnished by the engineers, and must be accompanied in a separate envelope by a certified check drawn on a solvent bank, made payable to the Treasurer of the State. Such courtesy. Invite the mailman, the grocery boy, the garbage man, the plumber, all the old lovers and the parish priest to a gang bang, courtesy of the house, and retain those disciples who are firm in faith, meek in spirit, and who appear to be favored 
by death in their quest for Divine Wisdom. Preach adultery as a world and life view.

More stocks rose than fell, but averages declined.

Learn how to pimp.

Get her a listing on the New York Stock Exchange.

Maintain constant alertness of consciousness in walking, sitting, eating, and sleeping through death. Paint the house red. Airlines rallied vigorously although the overall stock market showed conflicting patterns. Weakness in a number of outstanding blue chips accounted for the decline in the industrials. Cry for louder music and stronger wine.

Celebrate.

Slaughter lambs were steady to weak.

Ewes were unchanged, however.

Allow every man in the room to take Miss America upstairs and fuck her in the master bedroom, but avoid a death whose heart is set on acquiring worldly fame and possessions. As usual, good suspense and an interesting story line.

And then you die.

"THE LAST OF THE FAST GUNS!"

Music and dancing.

And the visions of her consume you.

(IN COLOR)

Buy cases of whiskey, hire a rock band, invite all the corporation presidents, all the automobile manufacturers, all the generals of death. Dark brown, with three heads, six hands, and four feet firmly planted on the four ends of the earth. FIRST TIME ON TV HERE! Miss America is strapped to a wheel which rotates uninterruptedly against an outer circle studded with razors and nails. 10:30 TONIGHT! The right face is white, the left face is blue, the middle face is red. Intruders at the Zambian Trade Fair in Ndola stole a live crocodile. While she's out getting screwed by someone else, you can sit home in bed and read Revelation while you wait for her to come back to your Home, Sweet Home, Where the Buffalo Roam, starring Jock Mahoney, Gilbert Roland, and Linda Cristal.

The body emitting flames of radiance.

The nine eyes widely opened, in terrifying gaze.

These sharp devices scratch, tear, and slice the unfortunate Miss America everywhere, from New York City to San Francisco, but tear gas grenades were fired into the crowd in an effort to disperse the mob. The eyebrows quivering like lightning, the protruding teeth glistening and set over one another, they screamed slogans in support of the guerrillas and carried banners denouncing the government, but notice the chill in the air.

England gave the world icily dry Gordon's Gin.

The three heads adorned with dried human skulls, but since the wounds are not deep, Miss America lives for at least two hours before bleeding to death, although plans had been established to keep the citizens behind a restraining fence. The eruption also unleashed a torrent of water from a lake more than 300 feet deep in the volcano's crater, but when the commander approached the fence to greet his admirers, they jumped over the fence, mobbed him, tore off his 
clothes, and grabbed at him so enthusiastically and patriotically that they castrated him, pulled off his arms and legs, and ripped off his head, which they subsequently placed in the regiment's trophy case, and America gave it icily refreshing Fresca.

Put them together in a glassful of rocks.

Gordon's and Fresca-jolly cool!

Black serpents and raw human heads form a garland for the body, but now she's stretched taut by pulleys attached to her arms and legs, and in the next few hours she's going to make love to another man. After five years of agony, you can give up those dreams of death and go out and preach the Second Coming. A curtain of ash descended on the town of Blitar and on coffee and tea plantations. She is lowered to a position two inches above a red-hot plate.

The first of the right hands holds a red Ford convertible.

The middle right hand holds an $\mathrm{ABM}$ missile.

The left right hand holds up a dismembered black man.

Miss America is melting, but if her unfaithfulness really bothers you, you must suffer like a saint because more meat, fresh fruits, and vegetables are being packaged in clear plastic trays so that the product can be inspected from both sides and not just on the top surface, and the first of the left hands holds a container of napalm, the middle one, a bowl of infant skulls, and the left one, a huge protest sign with the word FUCK written in beautiful gothic script, and that's okay with you, as long as she comes back in time to fix dinner.

She is attached by the waist to a burning iron rod.

Her body is embraced by a Green Bay Packer middle guard.

Her limbs are clamped in manacles which are twisted and turned until every joint in her body is dislocated, and if she really feels a compulsion to commit adultery, you could have a long talk with her and explain to her that you understand, that averting this heartbreak is now possible, according to Robert B. Greenblatt, chairman of the department of endocrinology at the Medical College of Georgia. When the sun sets and the lobster steams, Four Roses set the scene.

The Great American Spirit.

The whiskey that goes with the way we live.

Her right hand clings to his neck while her left hand holds up to his mouth a red shell filled with blood. She is suspended over a Texas barbecue by cords attached to her arms and legs because many a young girl's dream of becoming a long-stemmed American beauty has turned into a nightmare when she found herself growing too tall for the short, fat, sickly plantation owners of the Deep South. The cords are pulled tighter and tighter until these limbs are amputated, at which time her trunk falls into the barbecue pit. She embraces the Green Bay Packer on a dais supported by horned eagles of the One Hundred and First Airborne Division.

Do your feet stink?

Use a 30,000 line-per-minute Micromation printer.

There's a five-foot high, five-foot wide model that's big enough to seat two persons, or if you prefer, a model for a single bather. Snake-like movements of the backbone, a few sighs, and then she'll explore to make sure all equipment 
is in working order, but know this to be the embodiment of your own intellect. A General Electric stainless-steel pot, cooked until it is red hot, is fitted over Miss America's bald head.

Fear that not.

Perhaps you really are dull, pretentious, and stupid.

Considering the limitations of your present impact printer, you're getting short-changed 28,000 lines every minute. It is large enough that it doesn't touch her skin. And of course this leads nowhere. You are suffering from your own illusions; thus the skull slowly melts and the head is grilled and the brains are roasted, but she retains consciousness to the very end. You set it up in bedroom or bath, plug it into an ordinary 120 -volt socket and relax.

She is chained inside a vat of oil.

We've added ketchup, Molasses, Onions, and Bacon.

Then you come to the final judgment.

How will his family and associates adjust to a man whose substitute part is visible or audible? A fire is lit beneath the fat, bringing the liquid to a slow boil, and Campbell announces a new style in beans. She does not want children because they might take over some day, and consequently, there will be more allbeige and all off-white rooms this year, and when color is used, it will be in pale muted shades. Mothers have been adding their own homey touches to pork and beans for years.

The American Dream of sterility.

The stone surfacing is available in 50 designs, including some with Yucatan, Mayan, Gothic, South Seas, or American Indian art inspiration, and one of our new portable lasers puts out several million watts of peak power. Six feet, two inches. Blonde hair, blue eyes. Physique of a New York Giant halfback, mind of an atomic physicist, future of a black revolutionary. The 1970 tire swing is made of steel tubing with cushioned seats painted to look like tires, but it really might be your fault. Dear Heloise: The U.S. Department of Agriculture says it's time to fertilize your trees.

She needs variety, change, progress at all costs.

But you don't have to haul it around in a truck.

Mrs. Sylvia Bunch.

A girl is strapped before a mechanical bow which six times a minute shoots small arrows into her body, but if you want to know the kind of man he is, take a good look at the car he drives. Dear Heloise: I was given a silver casserole holder and it was never used until I decided to set a glass pie plate in it, then set my fern pot in the pie plate. It tickled at first, but after a while I got used to it. It's so very pretty, even though my husband is dying of cancer, the holder is in use daily. It's so much better than being tucked away where no one ever sees it, but then we see them preparing for battle, returning from it, treating the wounded, cremating the dead, raising pigs and sweet potatoes, dancing to celebrate the slaying of an enemy, performing rituals to placate their ghosts.

Maybe you're not that good in bed.

The way you brush your teeth.

The way you comb your hair. 
It could be a number of things.

The process continues until Miss America is completely and flawlessly feathered with arrows, and then Bert Parks sings the theme song, and then this America of Death ties a rope around your neck and leads you across the Mississippi. Dear Heloise: I have been pressing a lot of corduroy lately, but the problem demands a logical solution. SEE LANA TURNER AS MADAME X!! Your local Ziebart dealer will give you all the details. Dear Heloise: Before pouring off scalding water from boiled potatoes, turn on cold water tap to full steam.

No more scalded hands

THERE NEVER WAS A MAN LIKE SHANE!!!!

You expect too much from her.

A recent survey reports that there are 1,022 junkyards in the state covering 4,195 acres. This averages out to 10.33 junkyards and 42.38 acres for each county. Think of the possibilities. She is very slowly lowered, feet-first, into a vat of molten lead. She is chained by one hand to a flag pole. A heavy cannonball is attached to each of her feet. Eventually the weight of the cannonballs causes her hand to be severed, at which time she falls into a Bessemer furnace. She is melted, along with the scrap metal, into steel. The molten steel is poured into ingots, then transported to Detroit. She is again melted down into Nash Ramblers, Ford Galaxies, Lincoln Continentals, Buicks, and Pontiacs. And then this America of Death will cut off your head with Paul Revere silverware. Then we plug the holes with the little yellow Ziebart plug. And then Miss America's flesh is opened; her nerves are plucked out and tied in knots; then color television sets are issued to each member of the population.

THERE NEVER WAS A PICTURE LIKE SHANE!!!!

These boxed-in, hidden areas are where the rust begins.

Lockheed has better ways to make better decisions.

In practice this means that with a given amount of napalm to be airlifted, the number of deaths needed by available bureaucrats can be predicted accurately. She is hung from a rafter by a hook driven through her mouth and out of the back of her neck. And the next step is backwards, a gentle fall on the bed, she's very agile. Sure we're paying $4 \frac{1}{2} \%$ guaranteed interest on certificates of deposit. Dear Heloise: Within a few years Lake Erie, already one of the world's largest cesspools, will be unable to support almost any form of life, and then this America of Death will extract your heart and sew it on your sleeves with a Singer "ZIG-ZAG" sewing machine, but Princess Anne, in a recent photograph, holds her hand to her face as she arrives in London because she has a huge wart on her nose, but we uncoil the data transmitter.

And then she pulls out your intestines.

And then she licks up your brain.

And then she drinks your blood.

And then she eats your flesh.

And then she gnaws on your bones.

To do this, we make the shift frequency, which samples and shifts the input signal through the register, but you are incapable of dying. Every day, people buy new cars with all the extras, but after jumping, he will delay opening of his 
parachute until after he attempts to exceed the speed of sound in free fall, and this needs an additional analog to digital encoder and consequently another chip, but it's about $99 \%$ certain that Nick Piantanida will take off Sunday morning in his attempt at a record breaking free fall from an altitude of 123,000 feet, and they think the engine will take care of itself, but you know the bit: Crowded expressways, stop and go, all those Army convoys-although your body is hacked to pieces, it will revive again. The repeated hacking will cause intense pain and torture, but they did not give the number of planes involved. When she wants it, she doesn't fool around. She'll have him undressed before he can even unbutton her blouse ... or will she be wearing a sweater?

Is he a General Motors executive?

Does he work for Dow Chemical?

Brush your teeth with Colgate, but don't be frightened.

This electron-scattering experiment uses a beam of high energy neutrons.

And of course Miss America tries to create an illusion of virginity.

Clear skies, temperature in the high eighties, but tell no lies.

She pretends to be a benefactor of the poor. She distributes large quantities of meats and vegetables to them every holiday. No one realizes that the foods are poisoned until it's too late.

Though beheaded and quartered, your body is incapable of dying because it's a mental body.

This is a model of the bismuth nucleus, which has 126 neutrons and 83 protons; the number of neutrons is a "magic number," the number of protons nearly magical, and thus the nucleus is spherical.

A feigned clumsiness that twists her body in obscene attitudes of innocence.

In fact, though, arthritis is a disease of all ages.

DOWN TWO MIGS NEAR CHINA.

Surprised response to each clichéd touch.

Bayer works wonders.

The electrons strike the target and are deflected by its nuclei through various angles, but don't be terrified.

Fear not this America of Death.

The man imbeds the rocket, nose-first, into Miss America's Great Midwest. The fuse is then ignited. The rocket ascends, flies around and around, and finally crashes to the earth, all with the girl still attached. She does not die until the moment of impact.

The tremulo.

Power windows, power steering, power brakes.

In reality, your body is the nature of a void.

You need not be afraid.

Royal Triton Motor Oil works under any conditions.

The same man stuffs cartridges into each orifice of Miss America-the Pentagon, the White House, the Stock Market, the Television Set, the Daily Newspaper, the city of Chicago-and then he lowers her on pulleys into a fire.

After a few moments of this kind of play, she begins to lubricate in earnest. The cartridges explode simultaneously. 
Can you think of an easier way to save money?

Current and coming articles include:

Explosion in the Ghetto.

25 weeks of LIFE for only $\$ 2.95$.

And now she opens her legs.

A New Look at Menopause.

The effect is devastating.

This America of Death is your own hallucination.

The convulsions of the body, the pleading cry. . . .

Is Graphology Valid?

The tremulo of the voice that begs for violation.

Stimulating Executive Creativity.

Lucidity is the watchword.

Voidness and Brightness inseparable.

Degradation.

Self-Stimulation of the Brain.

Here comes Miss America.

The ADI-KAYA.

Howard Johnson's Restaurant.

Seaboard.

The same man shoves a lightning rod all the way up Miss America's Eastern

The Psychology of Power.

Then he hoists her up a flag pole during an apocalyptic thunderstorm.

Voidness cannot injure voidness.

She flutters in the breeze like a wheat field in Kansas.

Bill me after my subscription has ended.

The ADI-KAYA.

When the lightning finally strikes, she lights up like the end of things.

We watch the body burn until it turns black.

The Career Woman's Dilemma.

Then we pull down the corpse and carry it into Howard Johnson's Restaurant.

Group Therapy-Is It All Talk?

The ADI-KAYA.

Just fill out the coupon below.

We place Miss America on the imitation wood table.

We order a cup of coffee.

Then we fondle each crack and crevass of the body.

Then we mutilate the body.

Then we leave it on the table for the next customer.

Then we tip the waitress.

Then we leave.

The ADI-KAYA. 